\title{
Characterization of the production system and breeding practices of sheep producers in Tahtay Maychew District, Northern Ethiopia
}

\author{
AWOKE MELAK ${ }^{1, \vartheta}$, ABEBE HAILU ${ }^{1}$, ABRAHAM ASSEFA $^{1}$, TESFALEM ASEGED ${ }^{1}$, SEBLE SINKIE $^{1}$, \\ SEMERE TSION ${ }^{2}$ \\ ${ }^{1}$ Ethiopian Biodiversity Institute. Addis Ababa, Ethiopia. Tel.: +2519-2128-2957, `email: awoke.melak@yahoo.co.uk \\ ${ }^{2}$ Tahtay Maychew District Agricultural Burea, Ethiopia
}

Manuscript received: 1 January 2020. Revision accepted: xxx June 2021.

\begin{abstract}
Melak A, Hailu A, Assefa A, Aseged T, Sinkie S, Tsion S. 2021. Characterization of the production system and breeding practices of sheep producers in Tahtay Maychew District, Northern Ethiopia. Intl J Trop Drylands 5: 5-11. Sheep rearing plays an important role in the livelihoods of rural people in Ethiopia, yet limited information is available regarding the management system of the sheep. The study was conducted in Tahtay Maychew district of the central zone of Tigray, Northern Ethiopia. The objective of the study was to understand the sheep production system, the breeding practices, selection criteria, and sheep production constraints to identify sheep farming practices about future production strategies in the study area. A total of 70 households from 2 kebeles (lower administrative structure) were selected purposively based on sheep population and production potential and accessibility. Data was collected through semi-structured questionnaires, focus group discussions, and key informants. An index was calculated to provide an overall ranking of the purpose of keeping sheep, culling rams and ewe, according to the formula: Index $=\Sigma$ of [ 3 for rank $1+2$ for rank $2+1$ for rank 3]. It is concluded that both female and male sheep are maintained mainly for income generation followed by breeding. A variable that was given a higher priority in selecting breeding males and females was body size. Disease, feed shortage, lack of grazing, and predators are the major constraints of sheep production mentioned in the study area. Therefore, addressing these constraints is important to design a successful genetic improvement scheme in the area for sheep.
\end{abstract}

Keywords: Production systems, selection criteria, Tahtay Maychew

\section{INTRODUCTION}

It is believed that the livestock population in Ethiopia is the largest in Africa (Lijalem and Zeru 2016). Livestock is an important source of income for the agricultural community and is also one of Ethiopia's major sources of foreign currency through the exportation of live animals, meat, and skin (Lema 2015). The ongoing climate change is predicted to affect livestock sector in the country due to the long dry period and erratic rainfall, yet this issue has been only modestly considered (Niemi and Ahlstedt 2014). To overcome such problem, there is a need to conserve and sustainably use available local animal genetic resources which can adapt to the climatic condition. Conservation and sustainable utilization of local AnGR however requires information on their morphology and production system (Osei-Amponsah et al. 2017).

The huge livestock resources and diversified genetic pools in Ethiopia are adaptive to different agro-ecologies. Farm animals are raised across the highland, midland, and lowland areas of the country and they are integral parts of Ethiopia's agricultural system. Similar to livestock production in most developing countries, livestock management in Ethiopia is mostly subsistence-oriented and fulfills multiple functions that contribute more to food security (Duguma et al. 2010). Despite the large livestock resources with high potential for meat and milk production, several factors that influenced the development of the livestock sector in Ethiopia include the poor genetic performance of the indigenous animals, inadequate veterinary services, shortage of animal feeds as well as the absence of good management systems (Ergano 2015).

Sheep rearing is among the most crucial agricultural activities in the highlands of Ethiopia where crop production is unreliable. Sheep provide farm households with cash income, meat, fiber, and manure. As compared to large ruminants, small ruminants like sheep have shorter production cycles, faster growth rates, ease of management, and, low capital investment (Tadesse et al. 2015). In the absence of enough grazing land, small ruminants are efficient meat and milk producers for the smallholder farmers. They require small space and feed. These days, as a result of crop encroachment and degradation of communal grazing lands, there is a general shift in livestock holding from cattle to small ruminants because of the consistently dwindling grazing land (Taye et al. 2010). Feed scarcity, water shortage, disease/parasite, and shortage, market problem, inbreeding, capital problem, poor management, awareness problem, and untimely credit access are among the constraints for the sheep production system in Ethiopia (Feleke et al. 2015).

The main objective of this study is to characterize the production system, describe the production objectives and breeding practices of the sheep producers, generate information on the sheep breeds and breeding systems, and provide baseline information for designing breeding 
programs for Tigray sheep in the Tahtay Maychew District, Ethiopia.

\section{MATERIALS AND METHODS}

\section{Study area}

The study was conducted in Tahtay Maychew District of the central zone of Tigray in northern Ethiopia (Figure 1). The study district was selected for the reason that it is known as the center of distribution for Tigray sheep breeds. The study district covers a total area of $18,618 \mathrm{~km}^{2}$ and with an altitudinal range of 1992-2333 m.a.s.l. and lies approximately between $13052^{\prime}$ and140 19' North and 380 $29^{\prime}$ and $38042^{\prime}$ East. The mean annual temperature is about $19.90{ }^{\circ} \mathrm{C}$ and the minimum and maximum temperatures are $9.9^{\circ} \mathrm{C}$ and $30.3{ }^{\circ} \mathrm{C}$ recorded in December and June respectively. The estimated livestock population in the study district is about 247,907, consisting of 84,102 poultry; 75,707 cattle; 55,517 goats; 25,195 sheep; 6,716 donkeys; and 110 mules (Genet et al. 2015). The prominent farming system of the study area is mixed crop-livestock production.

\section{Sampling procedure and data collection}

Data was collected through interviews to randomly selected 70 sheep owners from Tahtay Maychew District. To check the clarity of the questionnaire to respondents and appropriateness of the questions, the questionnaire was designed, pre-tested, and modified before the commencement of the actual administration. Staff from the Ethiopian biodiversity institute administered the modified and finalized questionnaire. The questionnaire gathered information on socio-demographic characteristics of the households (age, gender, educational background, family size), livestock holding, flock characteristics (number and composition), source of income of the respondents, livestock and their importance, farming system characteristics, the purpose of keeping sheep, selection criteria of sheep, culling criteria of sheep, sheep diseases in the study area, and reproductive characteristics and constraints of sheep production in the study area.

\section{Data analysis}

The data was entered and analyzed by SPSS 23.0 software. Descriptive statistics of SPSS 23.0 software were used to describe the survey. An index was calculated to provide an overall ranking of the source of income of the respondents, importance of livestock, major crops cultivated, the purpose of keeping sheep, culling criteria of sheep, selection criteria of sheep, a major disease in the study area, and constraints of sheep production, according to the formula: Index $=\Sigma$ of [ 3 for rank $1+2$ for rank $2+1$ for rank 3] given for particular qualitative variables divided by $\Sigma$ of [ 3 for rank $1+2$ for rank $2+1$ for rank 3] for allqualitative variables. The rank was calculated by Microsoft excel 2010. The map of the study area was mapped with quantum GIS (QGIS 3.10.0).

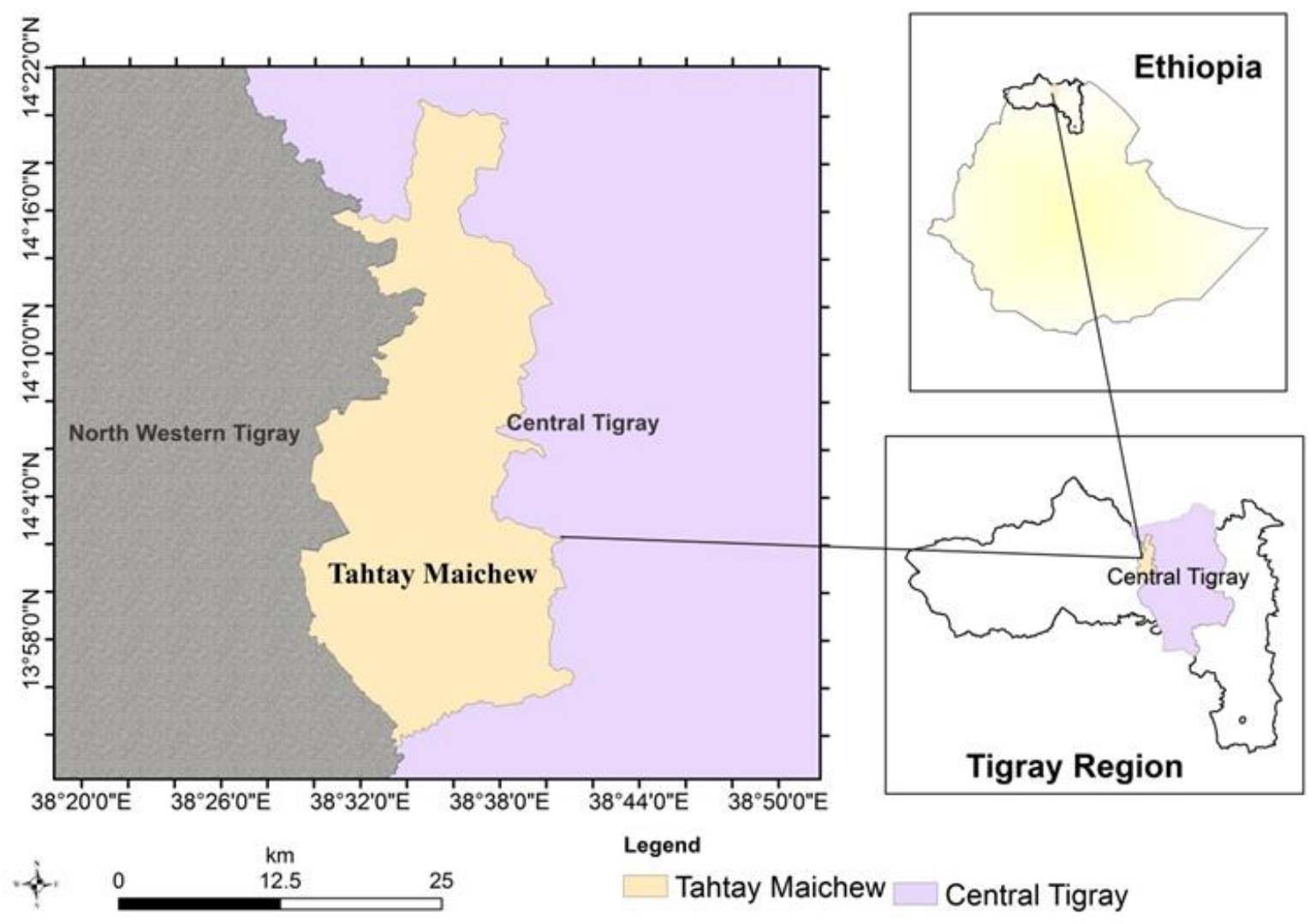

Figure 1. Map of the study area Tahtay Maychew District, Ethiopia. 


\section{RESULTS AND DISCUSSION}

\section{Individual and household characteristics of the respondents}

In the study area, the majority of the small ruminants owning households were male-headed $(93.2 \%)$ while the remaining were $(6.8 \%)$ were headed by females. The average family size of the households was $6.32 \pm 0.23$ (ranging from 2-11) and this result is lower than the report of Shimels Mengistu (2020) which is 7.66 persons. This may be due to low awareness of family planning. Many members within the family seem to be considered as an asset and security in times of retirement. The educational status of the respondents was illiterate, elementary, secondary, and informal education with proportion of $37.0 \%, 52.1 \%, 6.8 \%$, and $4.1 \%$, respectively.

\section{Livestock holding and composition}

The average reported livestock holding in the household is presented in Table 1. In Tahtay Maychew, the mean $( \pm$ SEM) number of cattle, sheep, goat, chicken, donkey, horse, mule, camel, and bee hives per household were $3.5068 \pm 0.33,8.16 \pm 0.59,1.55 \pm 0.33,4.19 \pm 0.41,0.74 \pm 0.11$, $0.03 \pm 0.03, \quad 0.03 \pm 0.03, \quad 0.07 \pm 0.04, \quad$ and $0.4 \pm 0.15$, respectively. Mostly the household head (husband) and spouse jointly are flock owners.

\section{Income sources of the respondents}

The source of income of the respondents is presented in Table 2. The respondents are mostly depending on crop cultivation followed by livestock rearing. The result also showed that trade is not such an important income source.

\section{Livestock and their importance in the study area}

The uses of livestock in the study area are presented in Table 3. As the result showed, cattle are the leading livestock species used for the lives of the respondents. Sheep and chicken are the second and third important livestock species, respectively.

\section{Farming system characteristics}

Most of the respondents in the study area practiced mixed farming system, both crop-livestock productions are integrated. According to the respondents, the major crops grown in the study area were teff (index $=0.38$ ), maize (index $=0.24$ ), sorghum, milt, wheat, barley, and bean with an index value of $0.14,0.14,0.05,0.03$, and 0.03 , respectively (Table 4). Crop cultivation was the most important sector in the crop-livestock production system and crop residues were the main source of feed for livestock. Livestock were invaluable components of the farming system in the study area and contribute enormously towards ensuring food security.

\section{Purpose of keeping sheep}

The reasons for keeping sheep depend on the long or short-term needs of the producers. The results of this survey revealed that sheep play multi-functional roles in the study district. Small ruminants are kept to meet both tangible and non-tangible benefits. The purpose of keeping sheep is presented in Table 5. Sheep are highly valued livestock species by the Tahtay Maychew people next to cattle and reared to fulfill diverse socio-cultural needs (Table 3). Sheep are slaughtered at wedding ceremonies, cultural festivals, and in honor of special guests and given as dowry.

Table 1. Mean $( \pm$ SEM) livestock holdings in the study district

\begin{tabular}{lc}
\hline Livestock & Mean \pm SEM $(\mathbf{N}=\mathbf{7 0})$ \\
\hline Cattle & $3.5068 \pm 0.33$ \\
Sheep & $8.16 \pm 0.59$ \\
Goat & $1.55 \pm 0.33$ \\
Chicken & $4.19 \pm 0.41$ \\
Donkey & $0.74 \pm 0.11$ \\
Horse & $0.03 \pm 0.03$ \\
Mule & $0.03 \pm 0.03$ \\
Camel & $0.07 \pm 0.04$ \\
Beehive & $0.4 \pm 0.15$ \\
\hline
\end{tabular}

$\mathrm{N}=$ number of respondents; $\mathrm{SEM}=$ standard error of the mean

Table 2. Source of income of the respondents

\begin{tabular}{lllll}
\hline Item & Rank 1 & Rank 2 & Rank 3 & Index \\
\hline Crop & 68 & 2 & 0 & 0.36 \\
Livestock & 2 & 67 & 0 & 0.24 \\
Salary & 0 & 0 & 3 & 0.01 \\
Trade & 0 & 0 & 0 & 0 \\
Other & 72 & 1 & 12 & 0.4 \\
Total & 142 & 70 & 15 & 1 \\
\hline
\end{tabular}

Table 3. Importance of livestock in the study area

\begin{tabular}{lllll}
\hline Livestock breeds & Rank 1 & Rank 2 & Rank 3 & Index \\
\hline Cattle & 47 & 11 & 3 & 0.43 \\
Sheep & 14 & 42 & 6 & 0.34 \\
Goat & 0 & 3 & 6 & 0.03 \\
Chicken & 1 & 6 & 19 & 0.09 \\
Donkey & 0 & 3 & 9 & 0.04 \\
Horses & 0 & 0 & 0 & 0 \\
Mule & 0 & 0 & 0 & 0 \\
Camel & 1 & 0 & 0 & 0.01 \\
Beehives & 3 & 0 & 5 & 0.04 \\
Others & 0 & 0 & 7 & 0.02 \\
Total & 66 & 65 & 55 & 1 \\
\hline
\end{tabular}

Table 4. Major crops and their importance

\begin{tabular}{lllll}
\hline Item & Rank 1 & Rank 2 & Rank 3 & Index \\
\hline Bean & 0 & 3 & 7 & 0.03 \\
Barley & 1 & 2 & 4 & 0.03 \\
Sorghum & 12 & 5 & 12 & 0.14 \\
Milt & 13 & 9 & 2 & 0.14 \\
Teff & 37 & 18 & 16 & 0.38 \\
Maize & 16 & 19 & 17 & 0.24 \\
Wheat & 0 & 9 & 2 & 0.05 \\
Total & 79 & 65 & 60 & 1 \\
\hline
\end{tabular}




\section{Culling reasons for sheep}

Livestock keepers need to evaluate each animal and decide whether that animal is productive or not, with increasing production costs. Nonproductive ewes and rams should not be maintained in the flock.

The best way to increase the efficiency of the sheep breeds is culling. Culling criteria for ewe and ram in Tahtay Maychew District with corresponding index values are presented in Table 6. Most of the respondents cull their breeding rams in which body conformation (index $=0.17$ ) and body condition ( index $=0.17$ ) were the most important ram culling criteria followed by color (index $=0.16$ ) and the next culling criteria were temperament and poor fertility with an index value of 0.14 and 0.13 , respectively. And again most of the respondents cull their breeding ewes in which poor fertility (index $=0.25$ ) and body size (index $=0.18$ ) were the most important ewe culling criteria followed by body conformation (index $=0.16$ ) and the next culling criteria were body condition and color with an index value of 0.13 and 0.10 , respectively.

As the study showed, the respondents cull their sheep mostly through sale and slaughter. As reported by Taye et al. (2010) sale of sheep at an early age is common in other areas too. This, the sale of young animals negatively influenced flock productivity that fast-growing and goodlooking lambs could be removed out from the flock before reaching breeding age and replacing themselves (Taye et al. 2010), and therefore drains the genetic pool of the flock. However, the practice can be taken as an efficient method of culling less productive and unselected animals out of the system, if properly managed. Therefore, care should be taken to maintain the productivity of animals while removing those with unwanted traits.

\section{Selection of breeding animals and trait preferences}

The most common way of selecting sheep as parents for the coming generations is to use the offspring of a chosen parent (ewe/ram). A linear index is the best strategy for selecting replacements in the livestock industries (Chawala et al. 2019). The selection criteria for ewe and ram in
Tahtay Maychew District with corresponding index values are presented in Table 7. Most of the respondents select their breeding ewes and rams in which body size (index $=$ 0.27 ) was the most important ewe and ram selection trait followed by body conformation (index $=0.26$ ) and the next selection criteria that the respondents prefer were growth performance and color with an index value of 0.24 and 0.18 , respectively. Therefore, this study is not in line with Haile et al. (2015) who reported that Basonawerena farmers do not include an appearance as a primary criterion for selecting breeding ewes. Instead, they ranked twining ability (index $=0.26$ ) as first, followed by age at first sexual maturity (index $=0.19$ ) and appearance (index $=0.14$ ).

Table 5. Purposes of keeping sheep

\begin{tabular}{lllll}
\hline Item & Rank 1 & Rank 2 & Rank 3 & Index \\
\hline Meat & 7 & 10 & 21 & 0.1 \\
Milk & 0 & 0 & 0 & 0 \\
Breeding & 27 & 23 & 8 & 0.21 \\
Manure & 36 & 15 & 5 & 0.23 \\
Blood & 3 & 0 & 0 & 0 \\
Hide & 0 & 0 & 0 & 0.01 \\
Hair & 0 & 0 & 0 & 0 \\
Income generation & 72 & 12 & 18 & 0.41 \\
Ceremonies & 1 & 5 & 9 & 0.03 \\
Others & 0 & 1 & 0 & 0 \\
Total & 146 & 66 & 61 & 1 \\
\hline
\end{tabular}

Table 7. Ranked selection criteria for breeding males and females

\begin{tabular}{lllll}
\hline Item & Rank 1 & Rank 2 & Rank 3 & Index \\
\hline Size & 26 & 9 & 16 & 0.27 \\
Conformation & 12 & 31 & 10 & 0.26 \\
Color & 4 & 17 & 29 & 0.18 \\
Temperament & 3 & 4 & 1 & 0.04 \\
Growth performance & 25 & 8 & 9 & 0.24 \\
Others & 1 & 0 & 0 & 0.01 \\
Total & 71 & 69 & 65 & 1.00 \\
\hline
\end{tabular}

Table 6. The culling reason for male and female sheep in Tahtay Maychew District

\begin{tabular}{|c|c|c|c|c|c|c|c|c|}
\hline \multirow[t]{2}{*}{ Item } & \multicolumn{4}{|c|}{ Male } & \multicolumn{4}{|c|}{ Female } \\
\hline & Rank 1 & Rank 2 & Rank 3 & Index & Rank 1 & Rank 2 & Rank 3 & Index \\
\hline Size & 2 & 4 & 4 & 0.05 & 14 & 7 & 6 & 0.18 \\
\hline Conformation & 9 & 16 & 4 & 0.17 & 9 & 13 & 4 & 0.16 \\
\hline Color & 6 & 14 & 12 & 0.16 & 2 & 8 & 14 & 0.10 \\
\hline Temperament & 11 & 6 & 5 & 0.14 & 3 & 1 & 3 & 0.04 \\
\hline Health problem & 3 & 4 & 7 & 0.07 & 3 & 10 & 3 & 0.09 \\
\hline Body condition & 15 & 6 & 5 & 0.17 & 3 & 13 & 10 & 0.13 \\
\hline Old age & 1 & 5 & 7 & 0.05 & 1 & 4 & 6 & 0.05 \\
\hline Poor fertility & 9 & 6 & 7 & 0.13 & 21 & 8 & 7 & 0.25 \\
\hline Others & 0 & 0 & 26 & 0.07 & 0 & 0 & 0 & 0 \\
\hline Total & 56 & 61 & 77 & 1 & 56 & 64 & 53 & 1 \\
\hline
\end{tabular}


Table 8. Major disease in the study area

\begin{tabular}{lcccc}
\hline Type of disease & Rank 1 & Rank 2 & Rank 3 & Index \\
\hline Stomach ache & 5 & 0 & 0 & 0.07 \\
Diarrhea & 19 & 1 & 1 & 0.29 \\
Mucus discharge & 9 & 3 & 0 & 0.16 \\
Dermal disease & 2 & 11 & 7 & 0.17 \\
Loss of appetite & 11 & 6 & 8 & 0.26 \\
Weight loss & 1 & 0 & 6 & 0.04 \\
Total & 47 & 21 & 22 & 1 \\
\hline
\end{tabular}

Table 9. Reproductive performances of Tigray sheep in Tahtay Maychew District

\begin{tabular}{lc}
\hline Reproduction parameters & $\begin{array}{c}\text { N=70 } \\
\text { (Mean } \pm \text { SEM) }\end{array}$ \\
\hline Average sexual maturity of male (month) & $6.76 \pm 0.20$ \\
Average sexual maturity of female (month) & $7.86 \pm 0.32$ \\
Age at first lambing (month) & $12.09 \pm 0.35$ \\
Lambing interval (month) & $7.26 \pm 0.31$ \\
Average market age of male (month) & $6.86 \pm 0.29$ \\
Average market age of female (month) & $7.66 \pm 0.30$ \\
\hline
\end{tabular}

Table 10. Major sheep production constraint in Tahtay Maychew District

\begin{tabular}{lcccc}
\hline \multicolumn{1}{c}{ Constraints } & Rank & Rank & Rank & \multirow{2}{*}{ Index } \\
\hline Lack of water & $\mathbf{1}$ & $\mathbf{2}$ & $\mathbf{3}$ & \\
Disease & 1 & 0 & 0 & 0.01 \\
Lack of drug & 30 & 9 & 0 & 0.34 \\
Lack of improved breed & 1 & 0 & 0 & 0.01 \\
Lack of grazing & 0 & 0 & 4 & 0.01 \\
Feed & 11 & 13 & 2 & 0.19 \\
Animal stole & 17 & 7 & 0 & 0.21 \\
Lack of vet & 0 & 0 & 1 & 0 \\
Lack of housing & 0 & 6 & 0 & 0.04 \\
Predator & 7 & 3 & 0 & 0.09 \\
Lack of proper management & 2 & 11 & 4 & 0.1 \\
Total & 0 & 0 & 0 & 0 \\
\hline
\end{tabular}

\section{Disease of sheep in the study area}

The major sheep health problems mentioned by the respondents are presented in Table 8 . In the study area, the most important sheep health problems mentioned by the respondents were diarrhea $(0.29)$, loss of appetite $(0.26)$, dermal disease $(0.17)$, mucus discharge $(0.16)$, stomach ache (0.07), and weight loss (0.04) (Table 8). As reported by Edea (2012) in Adillo Kaka, the most important sheep health problems were pasteurellosis, coenurosis, diarrhea, and lungworm. Edea (2012) also reported lungworm, liver fluke (fasciolosis), and coenurosis were mentioned as important health problems of Horro sheep producers, which is not in agreement with reports of this finding.

\section{Sheep breeding and reproduction performance}

Average sexual maturity of male and female sheep

The average age at sexual maturity for male and female sheep varies from breed to breed. Reproductive performances of Tigray sheep are summarized in Table 9. The average reported age at sexual maturity for Tigray sheep breeds were $6.76 \pm 0.20$ and $7.86 \pm 0.32$ months for male and females, respectively. The age at sexual maturity in this study is shorter than the finding of Edea et al. (2012) who reported that the average sexual maturity of Horro and Bonga sheep was $7.5 \pm 2.1$ and $9.3 \pm 2.2$ months for male and female sheep, respectively. Therefore, the age at sexual maturity in this study is not in agreement with Edea et al. (2012) who reported that average sexual maturity was $7.5 \pm$ 2.1 and $9.3 \pm 2.2$ months for males and females, respectively.

\section{Age at first lambing (AFL)}

The average AFL of the study area was $12.09 \pm 0.35$ months. The average age at first lambing for Tigray sheep breeds was shorter than 13.3 and 14.9 months reported by Edea et al. (2012) for Horro and Bonga sheep, respectively. Feed shortage and disease can also lead to delayed age at first lambing through limiting early animal growth. Year of lambing and season of birth, influence age at first lambing through their effect on feed supply and quality. The type of birth of the ewe/lamb significantly affects the age at which the ewe/lamb first lambed. The good performance of Tigray sheep breeds has an opportunity for genetic improvement as a greater population turnover and more rapid genetic progress.

\section{Lambing interval (LI)}

The average lambing interval of Tigray sheep was $7.26 \pm 0.31$ months (Table 9). It appears that this value is shorter than 8.9 and 7.8 months reported by Edea et al. (2102) for Bonga and Horro sheep, respectively. Tigray sheep breeds, under traditional management production systems, lamb three times in two years. This is in agreement with the literature (Mengistu 2020) who indicated that through the provision of better nutrition and management in organized farms of tropics it is practically possible to attain three lambings in two years. This kind of breeding schedule would permit the exploitation of the full reproductive potential, while at the same manner avoiding overly stressing females. To achieve such optimum reproductive performances from the Tigray sheep breeds, the prevailing feeding system needs to be adequate throughout the year.

\section{Market age}

The average market age of Tigray sheep in both sexes is not fixed. The market age of Tigray sheep is summarized in Table 9. The average reported market age for Tigray sheep breeds were $6.76 \pm 0.20$ and $7.86 \pm 0.32$ months for males and females, respectively.

\section{Major constraints of sheep production}

The major constraints of sheep production in the study area as mentioned by the households were disease, feed shortage and lack of grazing land, predator, and lack of housing (decreased in both size and productivity (Table $10)$. 


\section{Discussion}

The result showed that the majority of the small ruminants owning households were male-headed (93.2\%) while only small proportions $(6.8 \%)$ were headed by females. This finding is in line with Beyene (2018) that households were predominantly headed by males and that most livestock farmers are old aged are common phenomena in most developing countries. The current study described and documented Tigray sheep production systems in the traditional sector of Tahtay Maychew as an essential step towards the development of a sustainable breed improvement program.

Livestock farming was identified as the second activity in the study area; farmers had alternative means to source income. Similarly, farm produce alone could not sustain the household upkeep. Adem et al. (2018) attributed this to unreliable food crop yield in the province. 'Even in good years', the result showed that, 'crop cultivation is not enough to guarantee the respondents sufficient food and income for one year'. Hence, other sources of income (salary and others like labor work, selling wood and manure) reported in the current study, seemed to serve as supplements to farming income. This phenomenon presents an opportunity for sustainable utilization of indigenous livestock; which can withstand drought and can produce under conditions of low input and low-level management, thus requiring less input and availing farmers time to conduct other activities.

As the result showed, both female and male sheep are maintained mainly for income generation followed by manure and breeding. This builds financial capital and allows the sale of animals for cash that can be used for other agricultural enterprises, school fees, and medical bills, etc. Functions like hiding and hair received a lower ranking among sheep breeders. The purpose of keeping sheep for milk is zero, due to the culture of the society restricts not to drink sheep milk. As Mengistu (2020) reports, sheep milk is not used for drink and it is not also supplied to the market due to culture in acceptance of the society. Diverse functions are particularly important under the subsistence production system. The importance of diverse values of indigenous livestock breeds under low input system were well documented (Wurzinger et al. 2011)

The culling of rams for sale or family consumption is another possible factor contributing to the high proportion of ewes per flock in this study. One aim of this study was to document information that would be useful in the future when formulating a breeding program for Tigray sheep. As the result showed sheep were commonly used as a family income, manure, breeding, and source of meat. The other use mentioned by respondents was hiding. Only 15 farmers, in the Tahtay Maychew District, used sheep for ceremonies (Table 5). Teklebrhan (2012) mentioned that fibers, hides, skins, and pelts of indigenous sheep breeds are better than the crossbreeds. These could be possible opportunities that farmers can exploit to better utilize their indigenous sheep.

As the result showed most of the respondents' major cause of loss of sheep identified in this study was a disease with an index value of 0.34 . This concurred with findings by Weldemariam et al. (2014) that diarrhea and pneumonia are most commonly associated with an endemic condition in Ebinat and he ensured that poor health is the key limiting factor to productivity of sheep raised by most rural farmers in the study area. As reported by Weldemariam et al. (2014) most farmers interviewed depended on drug suppliers for veterinary help; this raises some doubts on the accuracy of the diagnosis of diseases. Maximum productivity in a given system of production emerges when disease control is optimal (Edea 2012). Thus, healthcare is an important problem to consider before the genetic program can be seriously contemplated. Community-based animal health programs may be one way forward and wider utilization of indigenous breeds tolerant to disease another (Mirkena et al. 2012). Feed shortage was identified as the second constraint for the sheep producers in the study area. Causes of feed shortage were due to human population growth, and frequent occurrence of drought, the low genetic potential of the breed, and lack of drug were ranked lowly in the study area. This might be due to a lack of awareness of sheep owners about genotype. Woldemariam et al. (2014) reported that pneumonia and diarrhea are the major cause of sheep mortality in the Ebinat district. Wendimu et al. (2016) also reported that the lack of strong animal health services and recurrent drought was mentioned as the main cause of sheep mortality. Another constraint for the sheep producers was the lack of grazing land. Other constraints such as lack of improved breed, lack of veterinary service, and drug identified in the present study were less significant (Table 10).

In conclusion, this study provides insight into agricultural production systems, breeding practices, and major production constraints encountered in sheep farming in the study area, which are preconditions in developing breeding programs. Livestock production is the main means of livelihood of the Maychew community in the study area. Cattle and sheep have a great role in the livelihoods of the community. Tigray sheep breeds are the most promising for their better adaptability under low input extensive production environments where scarcity of feed and grazing land are the two major constraints. Sheep are highly valued animals by the Tigrian people next to cattle and reared to fulfill diverse socio-cultural needs. Body size and growth performance are given high priority in selecting breeding males among his mates. Similarly for breeding female body size, body conformation and growth performance are among the most considered criteria for selection. Disease, feed shortage, and predators are the major constraints of sheep production in the study area.

To avoid early disposal of breeding males, strong extension service is required to convince farmers and to develop an interest in the benefits of better genotypes or incentives that might be provided for those keeping their best males for breeding purposes. Owing to the small flock size in the study area, reasonable genetic gain demands the formation of breeders' groups or co-operatives, which in turn require full participation and long-term commitment of sheep keepers and other livestock development actors. To realize the full benefits of breeding programs, approaches 
should be holistic, and a concurrent improvement in the non-genetic factors (disease and feed) is central.

\section{ACKNOWLEDGEMENTS}

The research was supported by Ethiopian biodiversity institute. The authors would like to thank everyone who has contributed to this study, especially Tahtay Maychew District farmers and livestock experts. We also would like to thank Tadese Hunduma for his support in the preparation of the map of the study area. The authors have not declared any conflict of interest.

\section{REFERENCES}

Adem M, Tadele E, Mossie H, Ayenalem M, Yildiz F. 2018. Income diversification and food security situation in Ethiopia: A review study. Cogent Food Agric 4 (1): 1513354. DOI 10.1080/23311932.2018.1513354.

Beyene A, Alilo AA, Mola M. 2018. Assessment of sheep and goat (small ruminants) production system in Esera District, of Dawro Zone, Southern Ethiopia. J Adv Dairy Res 6 (4): 215. DOI: 10.4172/2329. 888X.1000215.

Chawala AR, Banos G, Peters A, Chagunda MGG. 2019. Farmerpreferred traits in smallholder dairy farming systems in Tanzania Trop Anim Health Prod 51 (6): 1-8. DOI: 10.1007/s11250-01801796-9

Duguma G, Mirkena T, Haile A, Iñiguez L, Okeyo AM, Tibbo M, Rischkowsky B, Sölkner J, Wurzinger M. 2010. Participatory approaches to investigate the breeding objectives of livestock keepers. $\begin{array}{lllll}\text { Livest } & \text { Res } & \text { Rural } & \end{array}$ http://www.lrrd.org/lrrd22/4/dugu22064.htm

Edea Z, Haile A, Tibbo M, Sharma A, Sölkner J, Wurzinger M. 2012. Sheep production systems and breeding practices of smallholders in western and south-western Ethiopia: Implications for designing community-based breeding strategies. Livest Res Rural Dev 24 (7) http://www.lrrd.org/lrrd24/7/edea24117.htm

Ergano K, Duncan AJ, Klerkx L, de Boer IJM, Oosting SJ. 2015. Understanding socio-economic and policy constraints to dairy development in Ethiopia: A coupled functional-structural innovation systems analysis. Agric Syst 141: 69-78. DOI: 10.1016/j.agsy.2015.09.007.

Feleke FB, Berhe M, Gebru G. et al. 2016. Determinants of adaptation choices to climate change by sheep and goat farmers in Northern Ethiopia: the case of Southern and Central Tigray, Ethiopia. SpringerPlus 5: 1692. DOI: 10.1186/s40064-016-3042-3.
Genet A, Sebsebe D, Zerihun W, Sue E. 2015. Floristic composition of herbaceous flowering plant species in Lalay and Tahtay Michew Districts, Central Zone of Tigray, Ethiopia. Afr J Ecol Ecosyst 2 (6): 159-169.

Haile D, Gizaw S, Kefelegn K. 2015. Selection criteria, and breeding practice of sheep in a mixed crop-livestock farming system of North Shoa, Ethiopia. J Biol Agric Healthcare 5 (21): 168-174.

Lema H. 2015. The contribution of livestock in meeting food production and nutrition in Ethiopia. J Food Sci Technol 2 (3): 20-43.

Lijalem T, Zereu G. 2016. Production and reproduction performances of local dairy cattle: In the case of rural community of Wolaita Zone, Southern Ethiopia. J Fisheries Livest Prod 4: 176. DOI: 10.4172/2332 2608.1000176.

Mengistu S. 2020. Characterization of the production system and breeding practices of sheep producers in Doyogena district, Southern Ethiopia. Afr J Agric 11 (52): 5192-5201. DOI: 10.5897/AJAR2016.11825

Mirkena T, Duguma G, Willam A, Wurzinger M, Haile A, Richkowsky B, Mwai A, Solkner J. 2012. Community-based alternative breeding plans for indigenous sheep breeds in four agro-ecological zones of Ethiopia. J Anim Breed Genet 129 (3): 1055-1060. DOI: 10.1111/j.1439-0388.2011.00970.x.

Niemi M, Bläuer A, Iso-Touru T, Nyström V, Harjula J, Taavitsainen J-P. et al. 2013. Mitochondrial DNA and Y-chromosomal diversity in ancient populations of domestic sheep (Ovisaries) in Finland: Comparison with contemporary sheep breeds. Genet Sel Evol 45 (1): 1-14. DOI: $10.1186 / 1297-9686-45-2$.

Osei-Amponsah R, Skinner BM, Adjei OD, Bauer J, Larson G, Affara NA, Sargent CA. 2017. Origin and phylogenetic status of the local Ashanti Dwarf pig (ADP) of Ghana based on genetic analysis. BMC Genomics 18 (1): 1-12. DOI: 10.1186/s12864-017-3536-6.

Tadesse E, Negesse T, Abebe G. 2015. Sheep production and marketing system in southern Ethiopia: the case of Awassazuria district. Trop Anim Health Prot 47 (7): 1417-1425. DOI: 10.1007/s11250-0150852-1.

Taye M, Abebe G, Lemma S, Gizaw S, Mekoya A, Tibbo M. 2010. Traditional management systems and linear body measurements of Washera sheep in the western highlands of the Amhara National Regional State, Ethiopia. Livest Res Rural Dev 22 (9). http://www.lrrd.org/lrrd22/9/taye22169.htm

Teklebrhan T, Urge M, Mekasha Y. 2012. Carcass measurement, conformation, and composition of indigenous and crossbred (Dorper $\mathrm{x}$ Indigenous) F1 sheep. Pak J Nutr 11 (11): 1055-1060. DOI: 10.3923/pjn.2012.1055.1060.

Wendimu B, Kefelegn K, Mekasha Y, Shibabawu B. 2016. Phenotypic characterization of blackhead Somali Sheep in Gode and Adadile Districts, Ethiopia. J Glob Vet 17 (3): 265-270.

Woldemariam S, Zewde S, Hameto D, Habtamu A. 2014. Major causes of lamb mortality at Ebinat woreda, Amhara National Regional State, North-western Ethiopia. Ethiop Vet J 18 (1): 57-71.

Wurzinger M, Sölkner J, Iniguez L. 2011. Important aspects and limitations in considering community-based breeding programs for low-input smallholder livestock systems. Small Ruminant Res 98 (13): 170-175. DOI: 10.1016/j.smallrumres.2011.03.035. 